\title{
Sludge digester upset and recovery: modeling, monitoring, controlling and self curing
}

\author{
Ahmed M. Abou Elmagd \\ Department of Civil Engineering, Shoubra Faculty of Engineering, Sanitary and Environmental Engineering, Benha University. \\ Correspondence Author: Ahmed M. Abo-Elmagd, Department of Civil Eng., Shoubra Faculty of Engineering, Sanitary and Environmental Eng., Benha \\ University. \\ E-mail:- Ahmed.mahmoud@feng.bu.edu.eg ; ahmedcivil2003@yahoo.com
}

Received date: 18 May 2019, Accepted date: 20 September 2019, Online date: 29 September 2019

Copyright: (C) 2019Ahmed M. Abou Elmagd, This is an open-access article distributed under the terms of the Creative Commons Attribution License, which permits unrestricted use, distribution, and reproduction in any medium, provided the original author and source are credited.

\begin{abstract}
The aim of sludge stabilization is to reduce odor and putrescence problems as well as the risk of pathogenic organisms. Digesting sludge is the most effective way to stabilize sludge. The problem is that the high sensitivity to environmental conditions, especially the $\mathrm{pH}$, causes many sludge digesters to stop working and waste a lot of money in addition to environmental damage. This study was conducted to automatically monitor, control and recover anaerobic digestion without any human action. A bench-scale model was conducted to study the digester's response to organic overloading cases and also to study its response to recovery steps, aiming to apply these steps through programming an Arduino code. During the first run, the organic loading rate (OLR) was increased 1.5 times which lead to a little decrease in the PH, so the recovery was done by only suspension of the sludge feeding. During run 2 , the OLR increased 4 times to reduce the PH below 6 , so the recovery was done by adding 3 doses of lime $(27.1$ $\mathrm{ml}$ of $5 \%$ conc., each) with stopping the sludge feeding, until the PH became about 6.4, then 2 doses of lime, $13.55 \mathrm{ml}$ of $5 \%$ conc., combined with $10.2 \mathrm{ml}$ of $5 \%$ Soda Ash solution were added with continuation of feeding suspension. Using the results of the Bench scale model, the Arduino code was programmed, and the pilot scale model was constructed with a pH sensor, temperature sensor, methane concentration sensor, feed pump, lime pump and soda ash pump. The OLR was increased by 6 times, with pumps control was disabled, until the pH dropped below 6 then, automatic control by Arduino was allowed until the situation was treated and recovered. Results and observations were recorded and analyzed.
\end{abstract}

Key words: Sludge digester, Monitoring, Automatic control, Arduino.

\section{INTRODUCTION}

The aim of sludge stabilization is to reduce problems associated with the odor of sludge and decomposition, as well as to reduce the risk posed by pathogenic organisms (Veronica Arthurson, 2008). Sludge can be stabilized using lime, aerobic digestion or anaerobic digestion (Goldfarb et al., 1999). Lime stability is achieved by the addition of lime, either hydrated (Ca $\left.(\mathrm{oH})_{2}\right)$ or fast Lime $(\mathrm{CaO})$ to the sludge, raising the $\mathrm{pH}$ to 11 or above. This significantly reduces odor and helps in the destruction of pathogens. The main disadvantage of the stabilization by lime is that temporary action (J. Jeffrey et al., 1998). Aerobic digestion is an expected stabilization method for the activated sludge system. One disadvantage of this process is that digested sludge is more difficult to get rid of water by dewatering in the next stages (Demirbas et al., 2017).

Biochemistry of anaerobic digestion is a phased process: dissolution of organic compounds by extracellular enzymes followed by the production of organic acids by anaerobic microorganisms known as acid formers. Organic acids are turn into further degradation by methane formers (Jay N. Meegoda et al, 2018). These microorganisms are very sensitive for least change in their environment. the success of anaerobic treatment depends on maintaining the appropriate conditions for methane former because they are strict anaerobic, They are unable to producing methane and decompose of VFA in the presence of oxygen highly (In 't Zandt et al., 2018) and they are high sensitive to $\mathrm{pH}$, temperature, the presence of toxins or other environmental conditions (Wolfe R.S, 2011).

Most anaerobic digestion is mesophilic. it requires a constant temperature between $32-35^{\circ} \mathrm{C}\left(90-95^{\circ} \mathrm{F}\right)(\mathrm{Gerardi}, 2003)$. The fall of this condition can slow methane production, leading to the accumulation of volatile acids. One important consideration is not to allow any rapid temperature change. In mesophilic digestion, temperature should not be changed more than $2-3{ }^{\circ} \mathrm{C}$ per day 
(Gerardi, 2003). In fact, some sources have recommended only allowing $0.5^{\circ} \mathrm{C}\left(1^{\circ} \mathrm{F}\right)$ to be changed daily. It is important that in the case of temperature drop it should not recover very quickly. This can easily lead to an upset digester.

Alkalinity acts as a buffer against $\mathrm{pH}$ fluctuations in anaerobic digester. Volatile acid to alkaline ratio (VA / Alk) should be about 0.34 or less. When this ratio exceeds 0.5, the digester becomes unstable (Schnaars and Ken., 2012). VA / Alk Ratio is a much better indicator of digester sick than $\mathrm{PH}$.

Chandra (2009) and Gupta et al. (2013), investigated the biogas production from nonedible seed cakes. They reported that most of the anaerobic bacteria, including methane forming bacteria, perform well within a $\mathrm{pH}$ range of 6.8-7.2. A pH range of 6.5-7.5 is generally considered desirable

A decrease in $\mathrm{pH}$ is a clear indication of anaerobic digestion problems. Methane-forming bacteria break down fewer volatile acids outside the optimal $\mathrm{pH}$ range. This again leads to greater accumulation in disturbed acids.

High pH (7.2-8) can convert NH4 ions to NH3 (ammonia). NH3 is moderately toxic to digestion (above 50 ppm), but this problem generally corrects itself. This is because methane-forming bacteria cannot work well at high $\mathrm{pH}$ values and can cause accumulation of volatile acids that reduce $\mathrm{pH}$ to optimal levels.

If the $\mathrm{pH}$ is too low or too high, it is important to correct it quickly. Lime can be used to raise the pH to 6.4. Excessive feeding of lime can cause accumulation of solids which reduces the size of the digester (Abdallah and Kennedy, 2013).

Once the pH 6.4 is reached, the $\mathrm{pH}$ should be restored by bicarbonate salt. Sodium bicarbonate and potassium bicarbonate are the most commonly used salts. Potassium and sodium become inhibitors at 200-400 ppm and 100-200 ppm respectively (Mignone, 2005).

Alkaline acid can be calculated by dividing the total acid by the total alkalinity in the sample. The total alkalinity is measured by the $\mathrm{H} 2 \mathrm{SO} 4$ required to bring the sludge sample from $\mathrm{pH} 7$ to $\mathrm{pH} 4$. The total acid is measured using the amount of $\mathrm{NaOH}$ required to bring the sample from $\mathrm{pH} 4$ to 7 again.

Arduino is an open-source platform (M. Banzi, 2009) used for constructing and programming of electronics. It can receive and send information to most devices, and even through the internet to command the specific electronic device. It uses a hardware called Arduino UNO circuit board and software program (Simplified C++ (Minns, 2013) to program the board.

Nowadays Arduino are used a lot in microcontroller (Gibb, 2010) more than other things due to its user friendly, Like any microcontroller, arduino is a circuit board with a chip that can be programmed to perform a large number of tasks be sent from a computer program to the Arduino microcontroller and finally to the specific circuit or machine in order to execute the specific command. An Arduino can help you read information from input devices (Margolis, 2011) such as e.g Sensors, Antenna, Trimmer (potentiometer) etc... and can also send information to output devices such as LED (Margolis, 2011), Speakers, LCD Screen, DC motor etc.

$\mathrm{PH}$ is a measure of acidity or alkalinity of a solution, the $\mathrm{pH}$ scale ranges from 0 to 14 . The $\mathrm{pH}$ indicates the concentration of hydrogen $[\mathrm{H}]+$ ions present in certain solutions. It can accurately be quantified by a sensor that measures the potential difference between two electrodes: a reference electrode (silver / silver chloride) and a glass electrode that is sensitive to hydrogen ion. This is what form the probe. We also have to use an electronic circuit to condition the signal appropriately and we can use this sensor with a micro-controller, such as Arduino.

Methane sensor MQ-4 is a good choice. Because, It is cheap and works well. The sensor itself returns an analog voltage that can be converted using the ADC. or in other method, a mathematical formula can be used to convert analog values to methane concentration in ppm and can be programmed in Arduino coding language, as it was used in this study.

\section{MATERIAL AND METHODS}

\subsection{Bench scale model}

The sludge digester model consisted of a 5-liter jacketed glass reactor sealed with rubber stopper. The top cover was prepared by small mixer of $35 \mathrm{rpm}$. Inlet and outlet opening with valves were used to feed and discharge of the reactor.

The amount of gas was measured according to the water displacement principle. The reactor was connected to a 5-liter gas collector with P.V.C tube, which was connected to an open jar by another tube with valve. To keep the temperature at $35 \mathrm{C}$, the reactor was placed in a plastic basin provided by a water heater with thermostat. Fig.1a and fig.1b Show the bench scale model. 


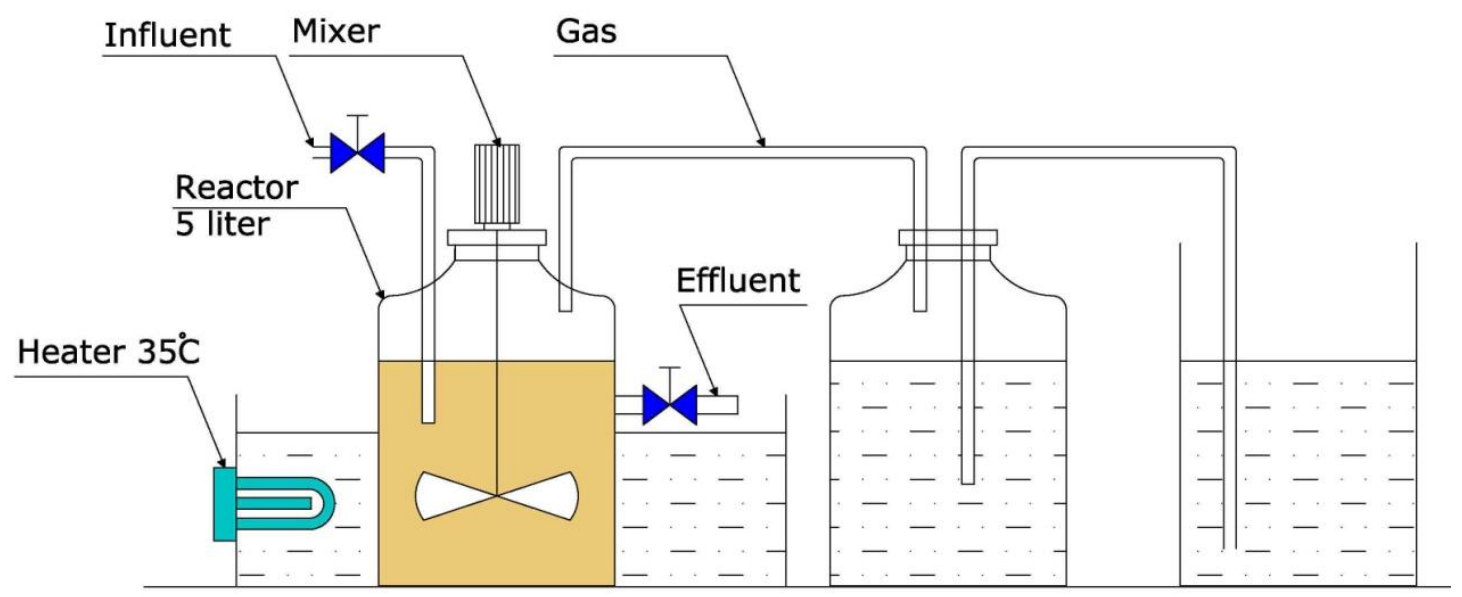

Fig.1a: Schematic diagram of bench-scale sludge digester model.

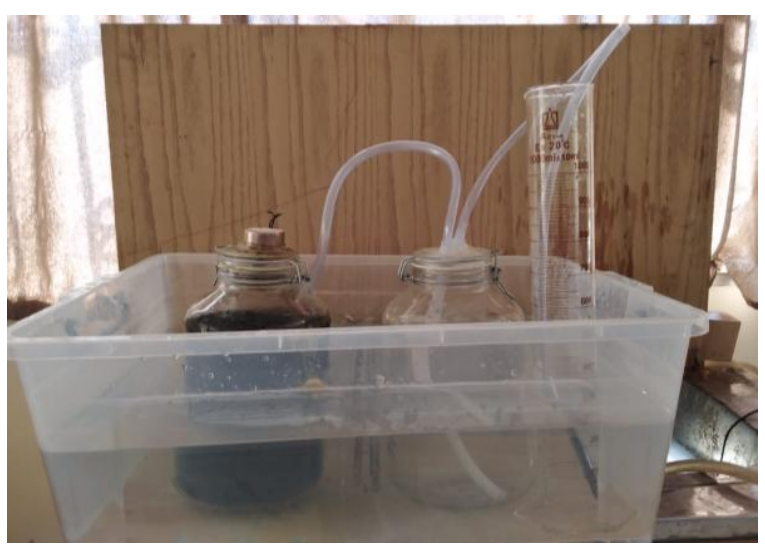

Fig.1b: Photograph of Bench-scale sludge digester model.

\subsection{Pilot scale Model}

Sludge digester reactor: The pilot scale reactor consisted of 128 liter glass Reactor. The reactor dimension was $0.4 * 0.4 * 1 \mathrm{~m}$ $(\mathrm{w} * \mathrm{~L} * \mathrm{~h})$ as shown in fig $(2 \mathrm{a} \& 2 \mathrm{~b} \& 2 \mathrm{c})$ with $0.4 * 0.4 \mathrm{~m}$ top glass cover sealed with rubber to prevent gas escaping. top cover was prepared by 5 openings, a sludge feed opening with inlet pipe extended under water surface level to allow sludge feeding without gas escaping, an opening for the motor and the mixer, an opening for sensors and heaters electrical cables, an opening for gas outlet, in addition to an opening for feeding of PH control solutions.

The Mixing: a 35rpm mechanical motor with mixer was used to achieve proper mixing that can help avoid high or low temperature local pockets, or accumulation of nutrients and toxins. This enables balanced function during digestion. Due to some problem in controlling motor and mixer, later on, recirculation pump was added to pump sludge from bottom of the reactor to top.

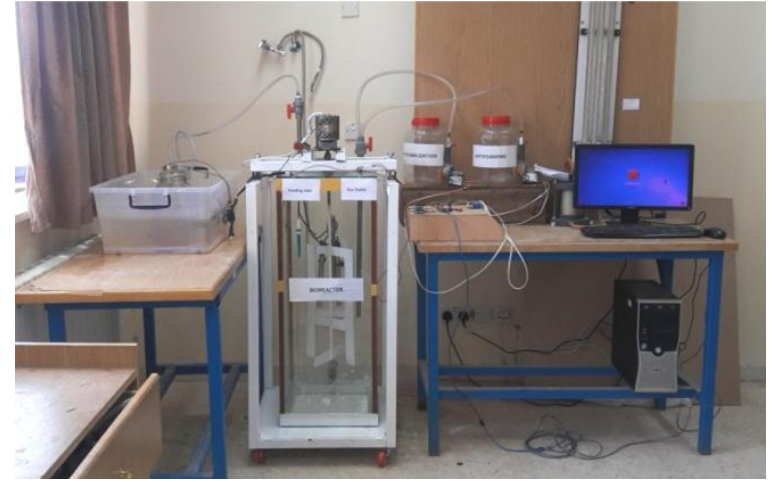

Fig.2a: Photograph for the digester

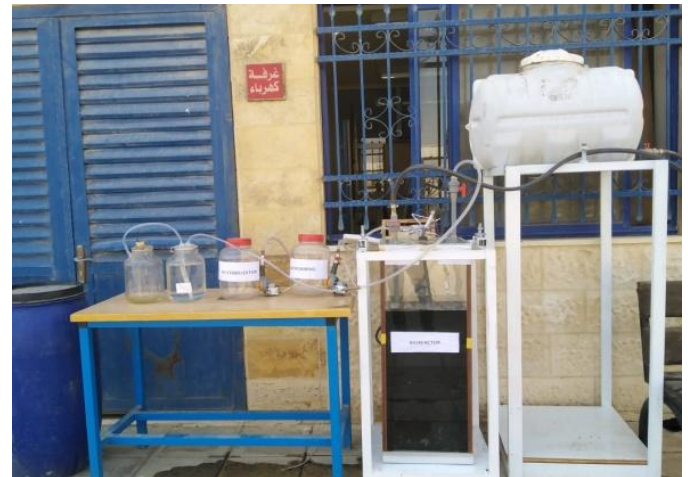

Fig.2b: Photograph during the experiment. 


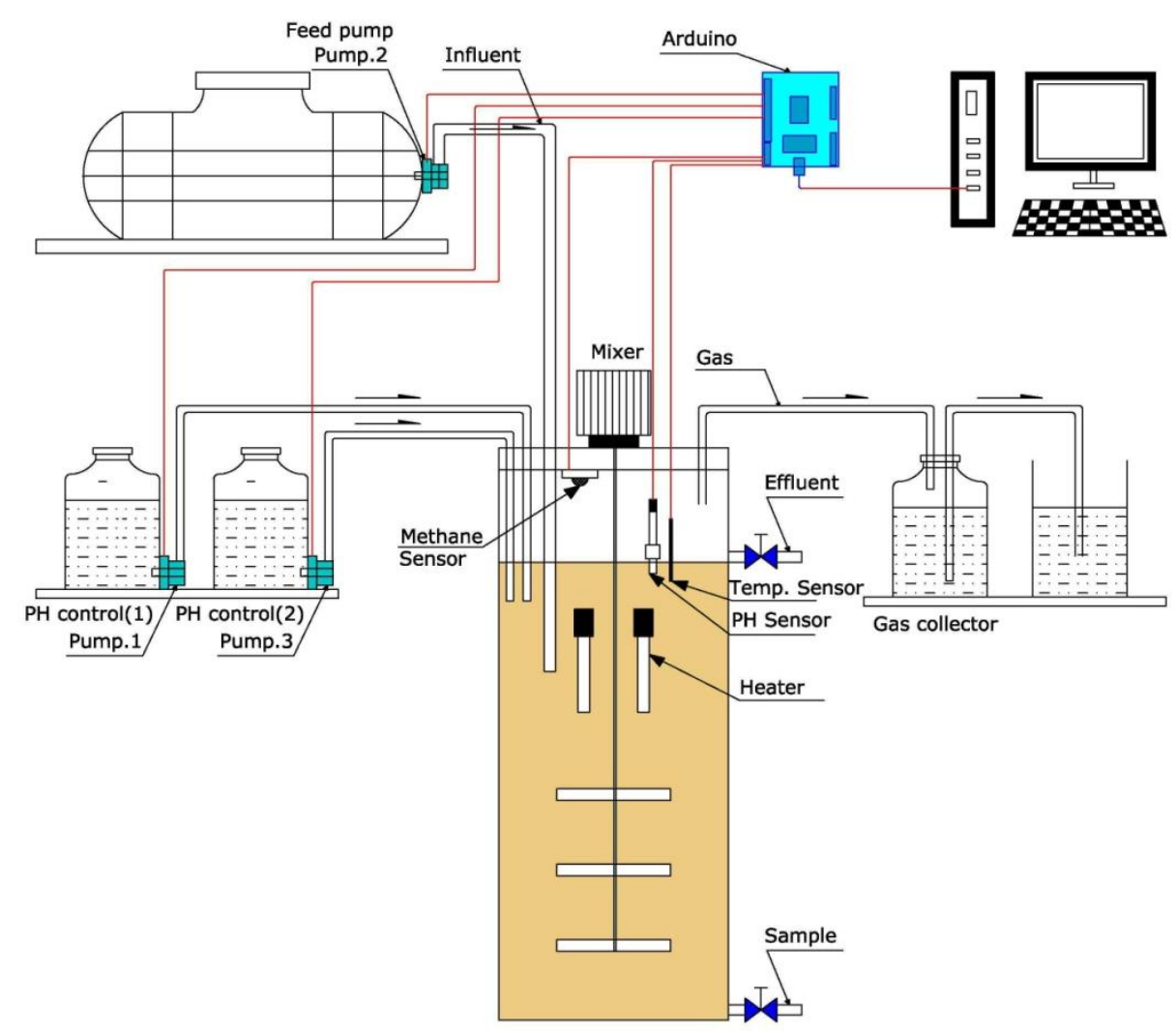

Fig.2c: Schematic diagram of pilot scale model digester

Gas measuring system: The biogas production was calculated by measuring the volume of the displaced water due to the pressure of biogas, for this purpose two, 5 liters, glass jars was used.

Sludge feeding: A 125 liter PVC tank was used for daily sludge feeding. The tank was elevated on a table, at a level higher than the top of the reactor. The mixed sludge was added to the reactor daily by a peristaltic pump connected to the Arduino control system (pump no. 2). The dose was adjusted by determining the opening time of the pump in the Arduino code.

PH control Solutions: Two plastic jars of 8 liters volume with pumps (pump no.1 and pump no. 3) were used to feed lime and soda ash to control PH. The two pumps of course connected to Arduino control system. The dose was adjusted by determining the opening time of the pump in the Arduino code.

The reactor body was provided by an outlet and sample opening at level $80 \mathrm{~cm}$ from the bottom. Also, there is a discharge opening near the bottom of the reactor.

Water Heaters: Two water heaters with thermostat were immersed in the fluid inside the reactor to maintain temperature at $35 \mathrm{c}$.

Arduino system: This study used the Arduino UNO circuit board and the "Simplified C ++" program specifically designed to program the Arduino board. The Arduino system consists of, (1) Analog PH sensor SKU:SEN0161 with calibration drops bottle, (2) MQ-4 Methane SENSOR, to measure methane concentration (3)Temperature sensor, (4) a set of 4 relays was used to connect the three pumps $(220 \mathrm{~V})$ to the Arduino Uno board ( $5 \mathrm{~V}$ ), and (5) USB cable to connect the system to PC computer 24 hours. As shown in fig.(3a\&3b). 


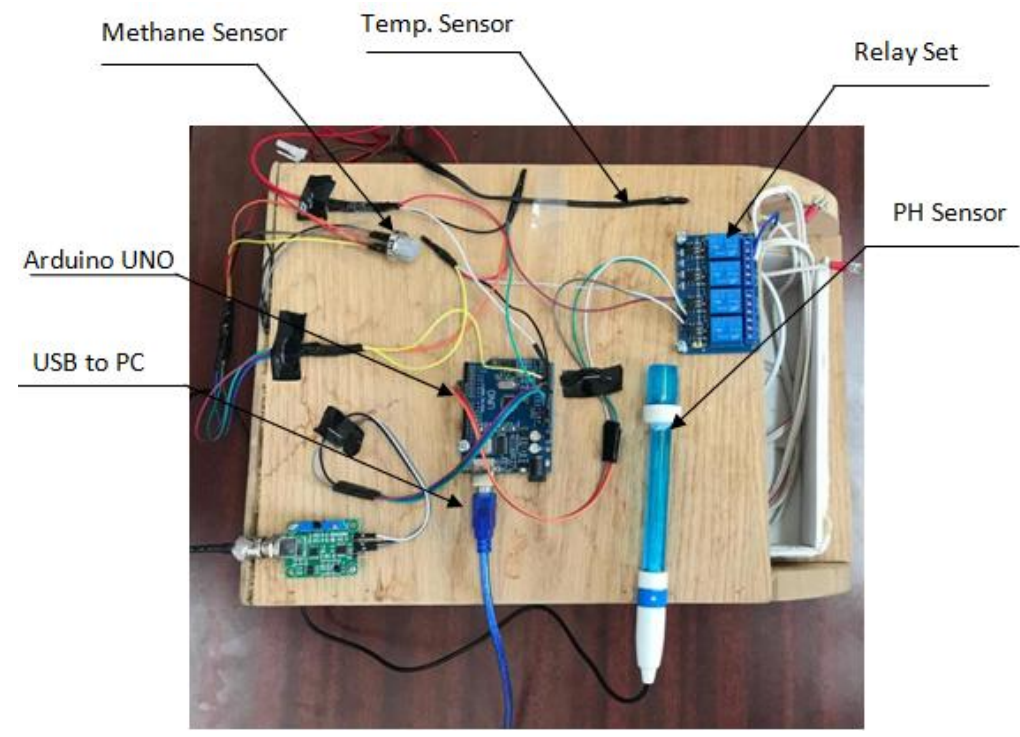

Fig.3a: Photograph for Arduino Uno board and sensors.

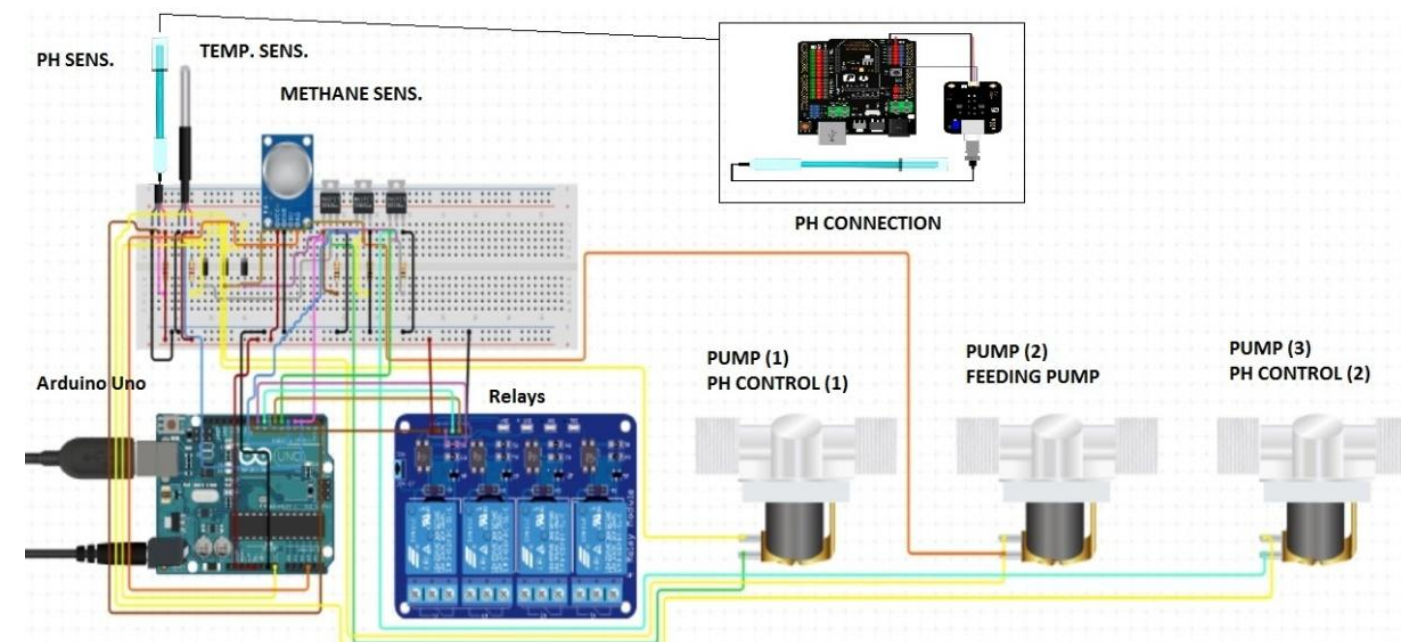

Fig.3b: Schematic diagram for Arduino board, sensors, relay and pumps, was drawn by using Tinkercad.

PH sensor (converting PH sensor voltage to PH value): Analog $\mathrm{pH}$ sensor SKU: SEN0161 was used in this study. PH sensor is connected first to the WeMos analog pin, then to the Arduino board as shown in Fig. (5b). PH is a measure of acidity or alkalinity, on a scale ranged from 0 to 14 . The $\mathrm{pH}$ indicates the concentration of hydrogen $[\mathrm{H}]+$ ions by a sensor that measures the potential difference between two electrodes. The relation between PH sensor voltage and PH values is linear. So by taking two points we can deduce the equation to convert the measured voltage to PH. Equation (1) and chart in fig.(4b) were used for this purpose. Fig. (4a) show the Arduino code written to convert $\mathrm{PH}$ sensor voltage to $\mathrm{PH}$ value.

Where: Y: PH value., X: PH voltage sent by sensor. 


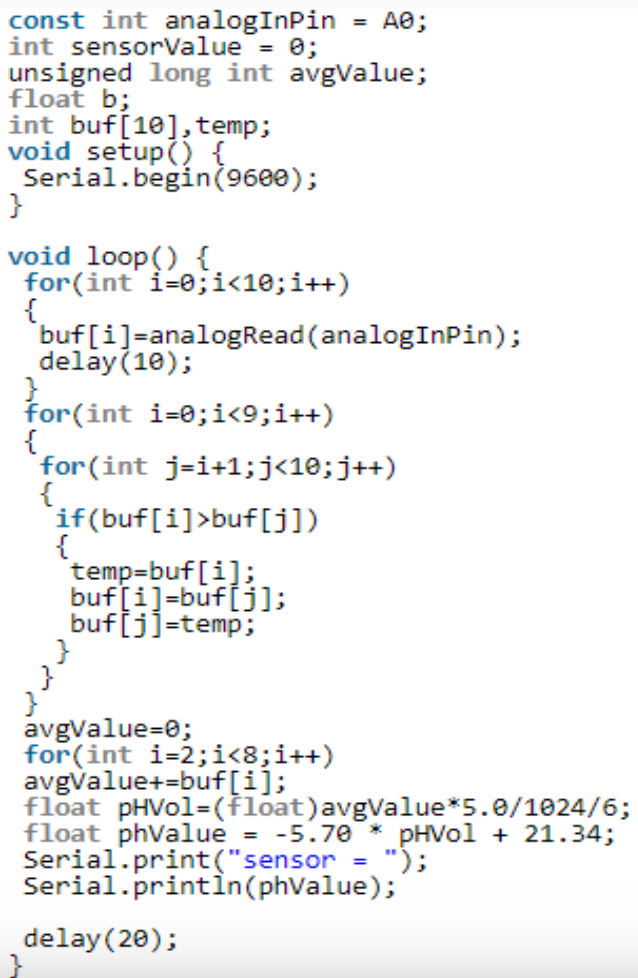

Fig.4a: Arduino code written to convert $\mathrm{PH}$ senso voltage to $\mathrm{PH}$ value.

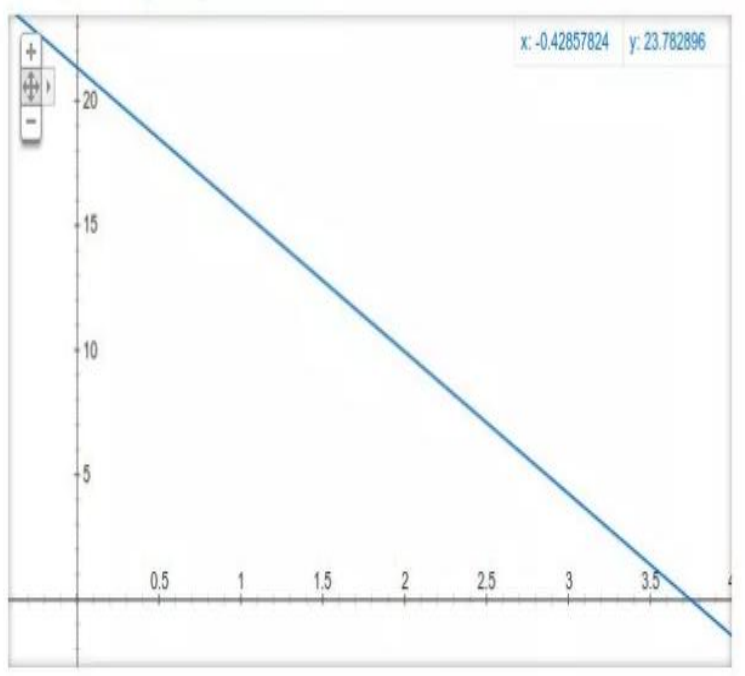

Fig.4b: chart used for converting $\mathrm{PH}$ voltage (on $\mathrm{X}$ axis) to $\mathrm{PH}$ value on (Y axis) (PH sensor data sheet).

\section{Methane sensor (convert Methane sensor volt to methane concentration in ppm)}

The MQ-4 methane sensor returns a voltage or resistance value that can be converted to Methane concentration in ppm using the chart fig.(5a), the Arduino code fig.(5b) and equation (2). As shown this sensor is suitable for detecting LPG, i-butane, propane, methane, alcohol, hydrogen, and smoke.

Rs/Ro $=-0.357 \mathrm{X}+2.477$

Where: X: is the methane concentration in PPM., Rs: sensor resistance at various concentrations of gases calculated depends on sensor volt. Ro: sensor resistance at 1000ppm of $\mathrm{CH} 4$ in the clean air, calculated from Rs divided by constant value for sensor.

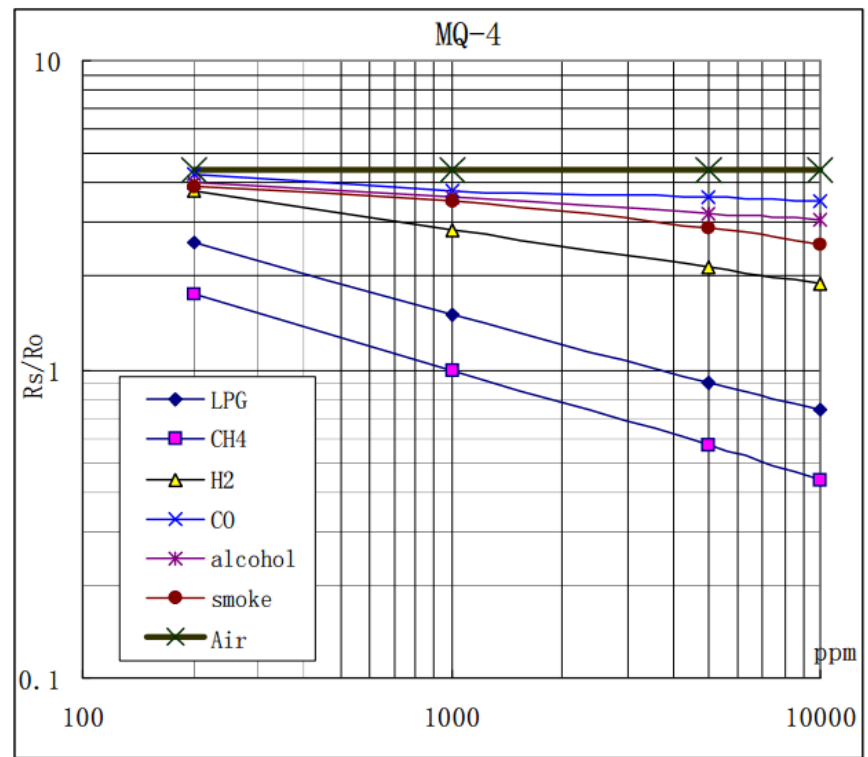

Fig.5a: chart of methane sensor MQ4, used for convert resistance voltage (on Y axis) to Methane concentration in ppm value on (X axis) (log-log paper) (Methane sensor data sheet). 


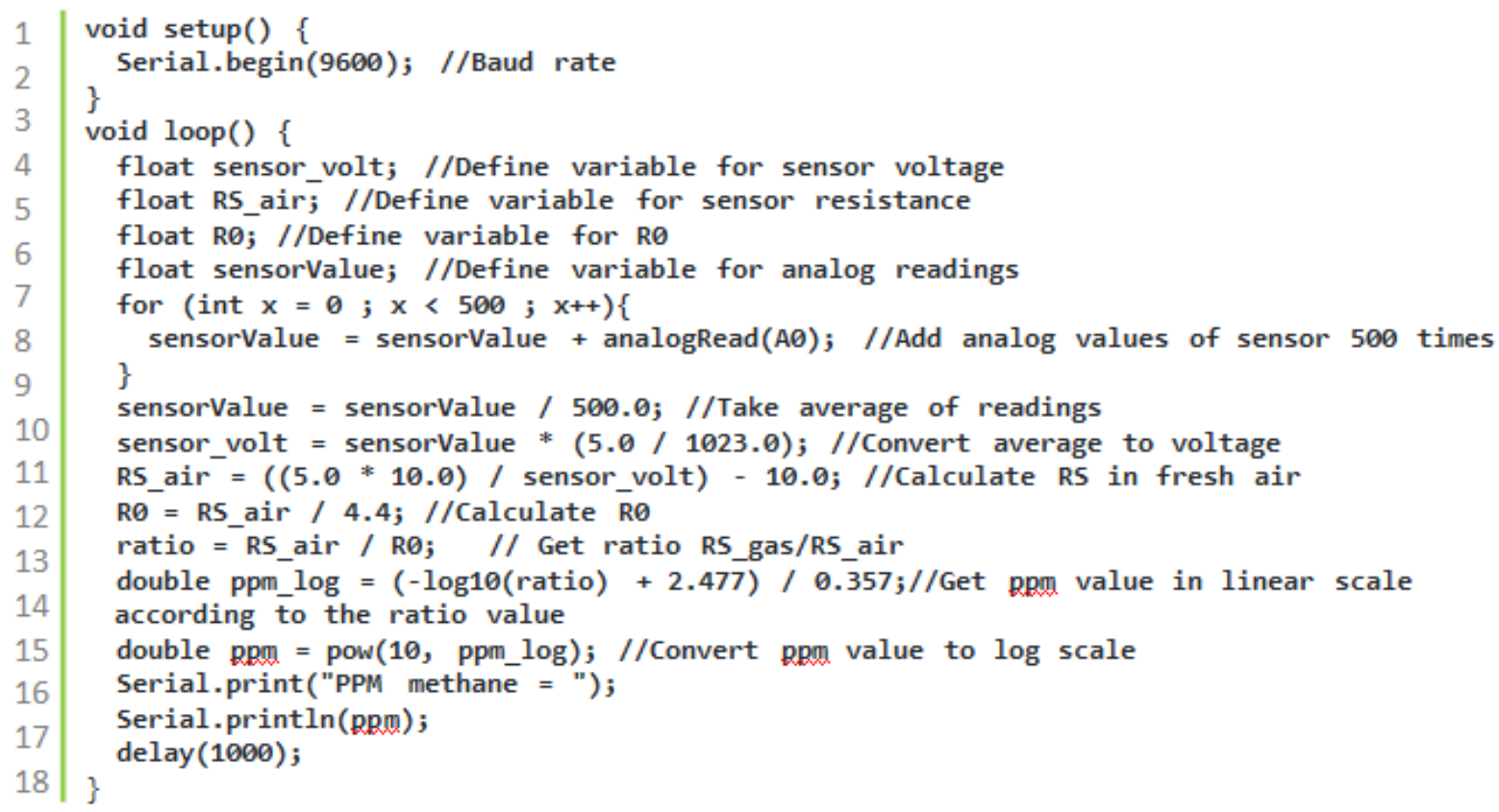

Fig.5b: Code written to convert Methane sensor voltage to Methane concentration in ppm.

\subsection{The Experimental Set-Up}

Mixed sludge was collected from Kherbet Elsamra wastewater Treatment plant, Zarqa, Jordan. Primary sludge was collected from primary settling tank, then thickened in a gravity thickener of effluent dry solids (DS) $53.39 \mathrm{~g} / \mathrm{l}$ and effluent volatile solids (VS) $37.62 \mathrm{~g} / \mathrm{l}$. Excess sludge from final settling tank, after aeration tank, was thickened in a floatation thickener and the effluent was $31.14 \mathrm{~g} / \mathrm{l}$ DS and $26.20 \mathrm{~g} / \mathrm{l} \mathrm{VS}$. The tow thickeners effluents were mixed together in a sludge mixing tank, in the WWTP, of effluent $46.10 \mathrm{~g} / \mathrm{l}$ DS and $34.50 \mathrm{VS}$, the sludge used in this study was collected from that mixing tank. Table (1) shows sludge composition taken from Kherbet Elsamra WWTP.

Table 1: Sludge composition taken from WWTP.

\begin{tabular}{|l|c|c|}
\hline & DS $(\mathbf{g} / \mathbf{l})$ & VS(g/l) \\
\hline Gravity thickener effluent & 53.39 & 37.62 \\
\hline Floatation thickener effluent & 31.14 & 26.20 \\
\hline Mixing tank effluent & 46.08 & 34.50 \\
\hline
\end{tabular}

The reactor outlet opening arranged at $0.8 \mathrm{~m}$ from the bottom, so the reactor Effective volume was 128 liter. Reactor was fed by 1.8 liter of mixed sludge three times daily. Feeding pump was automatically controlled by the Arduino system. Temperature was maintained at $35{ }^{\circ} \mathrm{C}$ by two water heaters with thermostats. To maintain OLR about $1.5 \mathrm{~kg} \mathrm{VS} \mathrm{m}-3$ day-1, the hydraulic retention time HRT was designed as 23 days according to influent VS concentration from mixing tank.

\subsection{Methodology}

The use of sludge digester in sludge treatment and biogas production has become very common during the design of new sewage treatment plants. However, over time, many sludge digesters are disrupted because of technical reasons related to controlling biological processes. Biological processes in general and specially Methane Forming Bacteria are very sensitive to the $\mathrm{pH}$ that should be between 6.8 and 7.2, which is a very narrow range (Chandra, 2009 and Gupta et al., 2013)

This study and the model have been done to facilitate monitoring and control over the operating conditions, especially the $\mathrm{pH}$, in addition to the possibility of treating the cause of the problem and recovery the appropriate operating conditions without any manual control.

PH sensors, methane sensors, and temperature sensors monitor digester performance and collect data then send it continuously to a PC monitor and to the Arduino, which was connected to three pumps to control the digester. A pump number 1 function was to add lime, pump no 2 was to control sludge feeding and pump number 3 was to add soda ash.

To program Arduino code, it was necessary to know the causes of digester disruption and how to treat it. For this purpose, a bench scale model was prepared, and two runs were performed.

Bench scale model: The digester was operated for 40 days without measurements until the digester performance rates became stable, at an OLR of $1.42 \mathrm{~kg} \mathrm{VS} / \mathrm{m} 3 / \mathrm{d}$, this corresponds to the load that occur in the WWTP that ranged between 1.4 and $1.8 \mathrm{~kg}$ $\mathrm{VS} / \mathrm{m} 3 / \mathrm{d}$. The reactor feeding rate was $0.25 \mathrm{~L} / \mathrm{d}$ divided into 3 doses with a 8-h interval, so the hydraulic retention time was 20 days. All times the temperature was maintained at $35^{\circ} \mathrm{C}$.

Run1: after startup period, During the first $24 \mathrm{hr}$, gas production, volatile Fatty acids (VFA) and alkaline (ALK.) were measured. Then the OLR was increased by 1.5 times during the next $24 \mathrm{hr}$ to allow the $\mathrm{pH}$ to drop but within a small range. To treat this, the digester feeding was stopped for 24 hours and the return to optimal rates was monitored. 
Run2: During the first $24 \mathrm{hr}$, gas production, VFA and ALK were measured. Then the OLR was increased by 4 times during the next $24 \mathrm{hr}$, in a stepwise fashion, to allow the PH to drop out of the allowable operating range to be about 6 . To treat this situation, the digester feeding was suspended for 48 hours. At the first 24 hours, 3 doses $27.1 \mathrm{ml}$ of $5 \%$ lime solution were added. At the next 16 hours, a dose of $13.55 \mathrm{ml}$ of the same lime solution in addition to $10.2 \mathrm{ml}$ of $5 \%$ Soda Ash solution was added twice with interval $8 \mathrm{hr}$. Table (2) shows the operating parameters during run1 and run2.

To increase the OLR without decreasing the hydraulic retention time (HRT), a 20\% dewatered sludge (without coagulant obtained from WWTP) was add to the feed doses.

Table 2: the operating parameters during run1 and run2.

\begin{tabular}{|c|c|c|c|c|c|c|}
\hline \multirow{3}{*}{$\ddot{\Xi}$} & $\begin{array}{l}\text { Time (hr) } \\
\text { (no of doses) }\end{array}$ & $\begin{array}{c}0,8,16 \\
(3)\end{array}$ & $\begin{array}{c}24,32,40 \\
(2)\end{array}$ & $\begin{array}{c}48,56,64 \\
(3)\end{array}$ & $\begin{array}{c}72,80 \\
(2) \\
\end{array}$ & $\begin{array}{c}88,96,104 \\
(3)\end{array}$ \\
\hline & Influent S.S \% & $3.80 \%$ & $5.70 \%$ & - & $3.80 \%$ & $3.80 \%$ \\
\hline & OLR (Kg VS/m3/d) & 1.425 & 2.1375 &,,$-- 1.425(1)$ & 1.425 & 1.425 \\
\hline \multirow{4}{*}{$\stackrel{N}{\Xi}$} & Influent S.S \% & $3.80 \%$ & $15.20 \%$ & - & - & $3.80 \%$ \\
\hline & OLR (Kg VS/m3/d) & 1.4250 & 5.7000 & - & - & 1.425 \\
\hline & Lime ml (5\% con.) & - & - & 27.1 & 13.55 & - \\
\hline & Soda ash ml (5\% con.) & - & - & - & 10.2 & - \\
\hline
\end{tabular}

Pilot Scale Model: In this stage, the Arduino code was programmed according to the results obtained from Bench scale model. Then OLR was increased until became overloaded to check how the automatic control could cure the reactor operating conditions. A $128 \mathrm{~L}$ digester was operated for 40 days without measurements until the digester performance rates were stable, at an OLR of $1.5 \mathrm{~kg} \mathrm{VS} / \mathrm{m} 3 / \mathrm{d}$ and the temperature was maintained at $35^{\circ} \mathrm{C}$. the digester feeding rate was $5.56 \mathrm{~L} / \mathrm{d}$ divided into 3 doses separated by 8 hours, so the hydraulic retention time was 23 days. in the day 41, day zero, gas production, VFA and ALK were measured every 8 hours. The digester was then subjected to 3 pulse loads spaced by 4 hours. Each pulse was of $0.47 \mathrm{~L}$ of $20 \%$ dewatered sludge and $1.38 \mathrm{~L}$ of $4.6 \%$ thickened sludge, which achieve approximately $9 \mathrm{~kg}$ VS m-3. Dewatered sludge was taken from dewatering stage by centrifugation in WWTP (without coagulant).

All pumps have been turned off during the chock loading period to allow the pH to drop below 6 and were then reoperated and automatic control by Arduino was allowed. The Arduino stopped the feeding by closing pump no 2 , for 40 hours. Also, opened pump no. 1, to add 3 doses $700 \mathrm{ml}$ of $5 \%$ lime solution during the first 24 hours. At the next 16 hours, the Arduino opened pump noland pump no 2 to add 2 doses $350 \mathrm{ml}$ of the same lime solution in addition to $250 \mathrm{ml}$ of $5 \%$ Soda Ash solution in each dose. Table (3) shows the operating parameters.

Table 3: the operating parameters in pilot scale model.

\begin{tabular}{|l|c|c|c|c|c|}
\hline $\begin{array}{l}\text { Time (hr) } \\
\text { (no of doses) }\end{array}$ & $\begin{array}{c}\mathbf{0 , 8 , 1 6} \\
\mathbf{( 3 )}\end{array}$ & $\begin{array}{c}\mathbf{2 4 , 3 2 , 4 0} \\
\mathbf{( 3 )}\end{array}$ & $\begin{array}{c}\mathbf{4 8 , 5 6 , 6 4} \\
\mathbf{( 3 )}\end{array}$ & $\begin{array}{c}\mathbf{7 2 , 8 0} \\
\mathbf{( 2 )}\end{array}$ & $\begin{array}{c}\mathbf{8 8 , 9 6 , 1 0 4} \\
\mathbf{( 3 )}\end{array}$ \\
\hline Influent S.S \% & $4.60 \%$ & $27.60 \%$ & - & - & $4.60 \%$ \\
\hline OLR (Kg VS/m3/d) & 1.500 & 9.00 & - & - & 1.5000 \\
\hline Pumps control & Off & Off & On & On & On \\
\hline Lime (ml) (5\% con.) & - & - & 700 & 350 & - \\
\hline Soda ash (ml) (5\% con.) & - & - & - & 250 & - \\
\hline
\end{tabular}

\section{RESULTS AND DISCUSSION}

\subsection{Bench scale results}

In purpose to program the Automatic controlling code by Arduino, run 1 and 2 were conducted on the Bench scale model to understand the digester behavior when exposed to organic shock loads and then to understand its response during the treatment procedures.

Run1 Results: OLR was increased from 1.42 to $2.1 \mathrm{~kg}$ VS/m3/d to decrease the PH slightly, but still in acceptable operating limits. The results showed a decrease in the $\mathrm{pH}$ from 7.18 to about 6.75 with an increase in the OLR, but it is still close to 6.8 which is the appropriate minimum limit for the biological processes inside the digester. Therefore, the feeding was closed, and the $\mathrm{pH}$ began to increase gradually. Suspension of feeding give enough time to, methane forming bacteria, to consume VFA and allow Alk to raise PH (Mohammed Ali Musa et al, 2018). Fig. (6a) show the change in OLR in kg VS/m3/d and PH with time. 


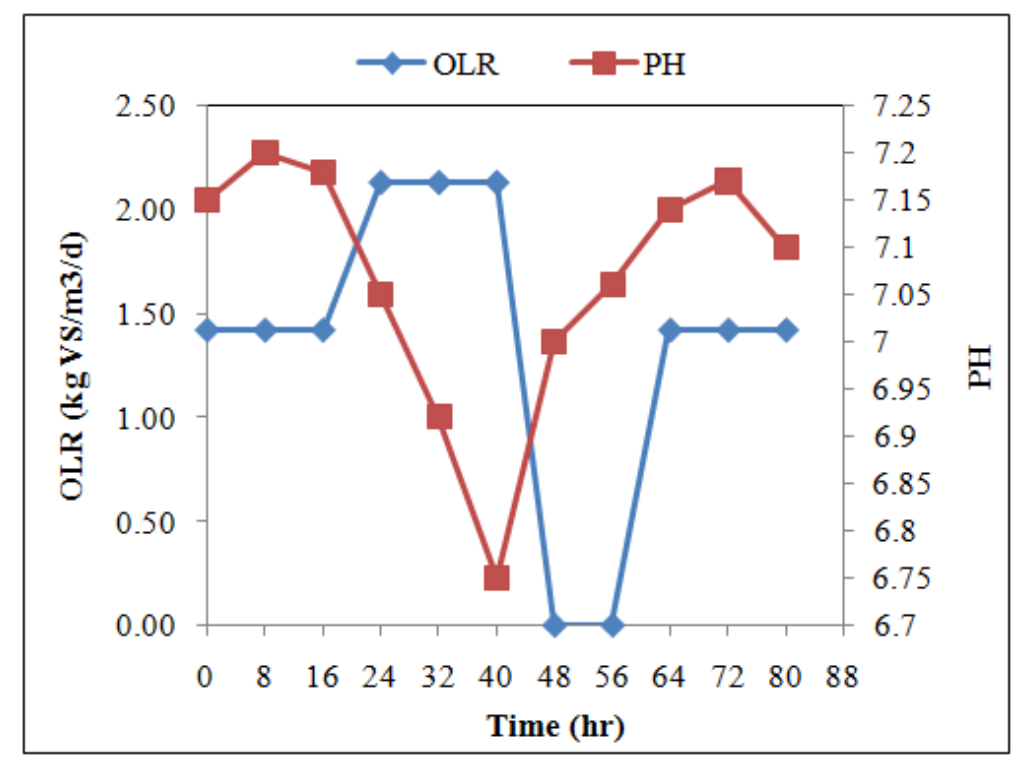

Fig. 6a: change in OLR (kg VS/m3/d) and PH with time (hr) in (bench scale model, Run1).

VFA also risen to 5 times its first value with the increase of OLR, this is due to the accumulation of VFA and the inability of methane-forming bacteria to consume it. Accumulation of VFA leads to decrease PH, which leads to the inhabitation of methane-forming bacteria. Stopping the digester nutrition gives the bacteria a chance to convert volatile fatty acids into biogas. Alkalinity also decreased slightly with the increasing of OLR. Fig.(6-b) show the change in VFA in (mg of acetic acid/L) and Alkalinity in (mg/l as Caco3) with time (Chen at al. 2015).

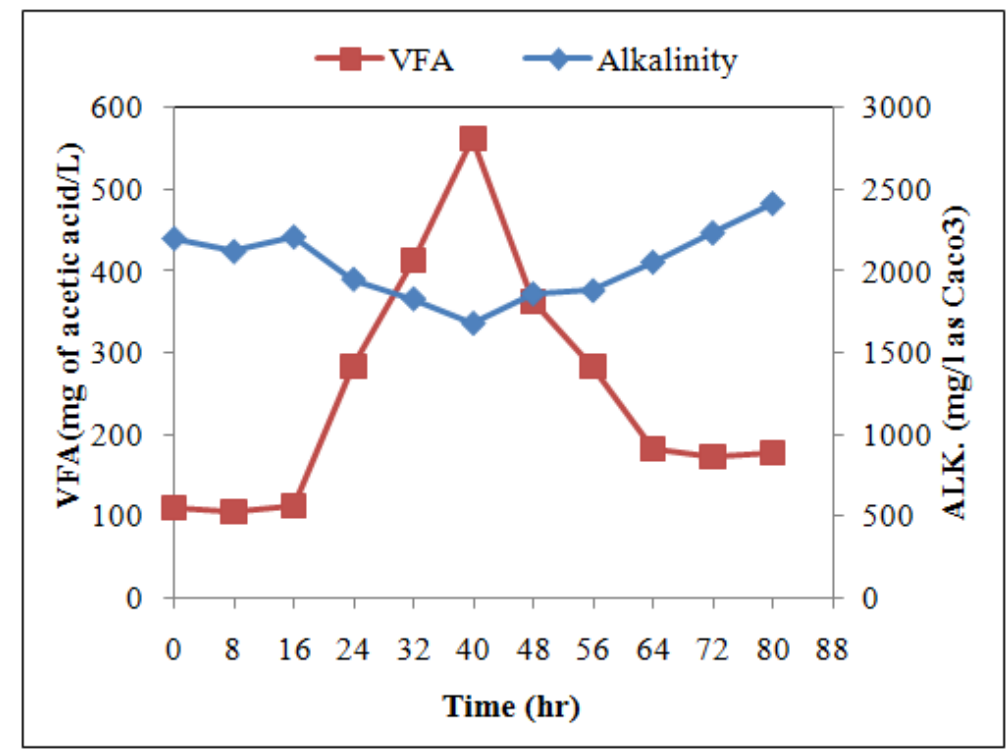

Fig.6b: change in VFA in (mg of acetic acid/L) and Alkalinity in (mg/l as Caco3) with time (hr) in (bench scale model, Run1).

With the increase of OLR, VFA/Alk increased but still remained within the safe limits and therefore, the performance of the methane-forming bacteria was not affected, and gas output remained almost the same. Fig. (6c) shows the change in gas production rate in $(\mathrm{L} / 8 \mathrm{hr})$ ) and VFA/Alkalinity ratio with time. 


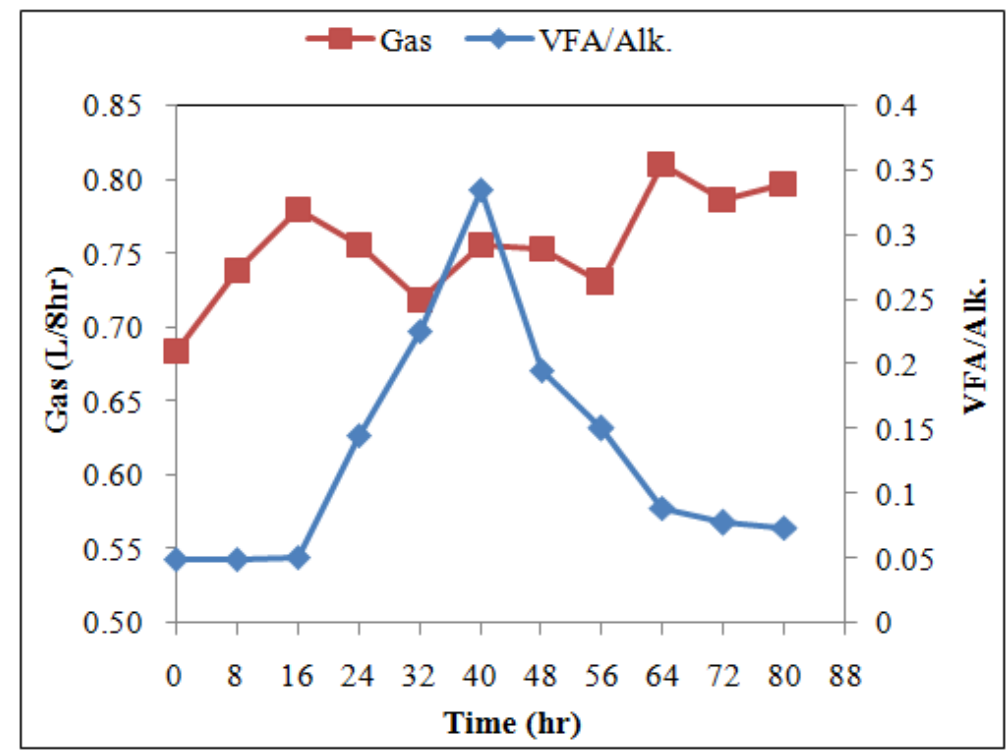

Fig.6c: change in gas production rate in (L/8hr) and VFA/Alkalinity ratio with time (hr) in (bench scale model, Run1).

Run2 Results: OLR was increased from 1.42 to $5.7 \mathrm{~kg}$ VS / m3 / d in order to reduce $\mathrm{pH}$ less than 6 . With the increase of OLR, the $\mathrm{pH}$ decreased to 5.9. Therefore, feeding was stopped and three consecutive doses of lime (27 $\mathrm{ml} \mathrm{conc.} \mathrm{5 \% )} \mathrm{separated} \mathrm{by} 8$ hours were added. The $\mathrm{pH}$ began to rise but stopped at around 6.4 and so, the addition of lime again will cause accumulation inside the digester without effect. As a result, two doses of soda ash $(10.2 \mathrm{ml}$ conc.5\%) were added in addition to half the dose of lime as the feed continued to be closed. This causes the $\mathrm{pH}$ to rise to 6.9. Figure (7a) show the change OLR in $\mathrm{kg} V \mathrm{VS} / \mathrm{m} 3 / \mathrm{d}$ and $\mathrm{PH}$ with time.

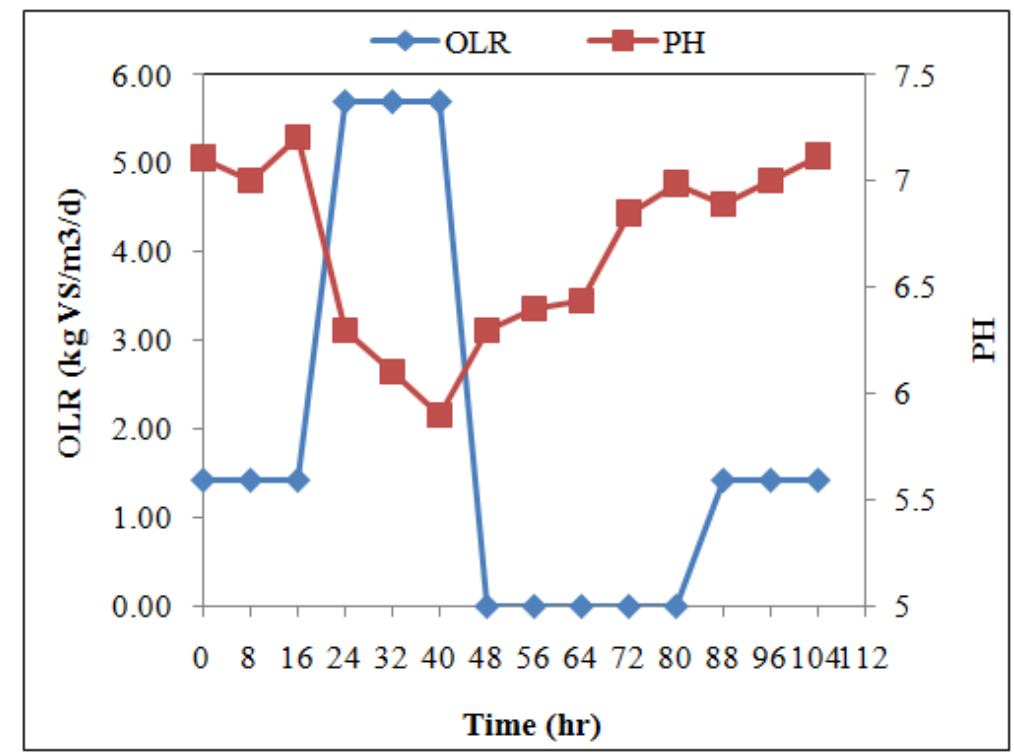

Fig.7a: change in OLR (kg vs/m3/d) and PH with time (hr) in (bench scale model, Run2).

VFA have also risen to 910 (mg of acetic acid/L) as the OLR increase, this is due to the accumulation of VFA and the inability of methane-forming bacteria to consume it. Therefore, stopping the digester nutrition gives the bacteria a chance to convert volatile fatty acids into biogas. Alkalinity also decreased to $480(\mathrm{mg} / \mathrm{L}$ as Caco3) with the increase of OLR, and the results were then reversed with stopping feeding and adding lime and soda ash until it reached its initial rates. Figure (7b) show the change in VFA in (mg of acetic acid/L) and Alkalinity in ( $\mathrm{mg} / \mathrm{l}$ as Caco3) with time. 


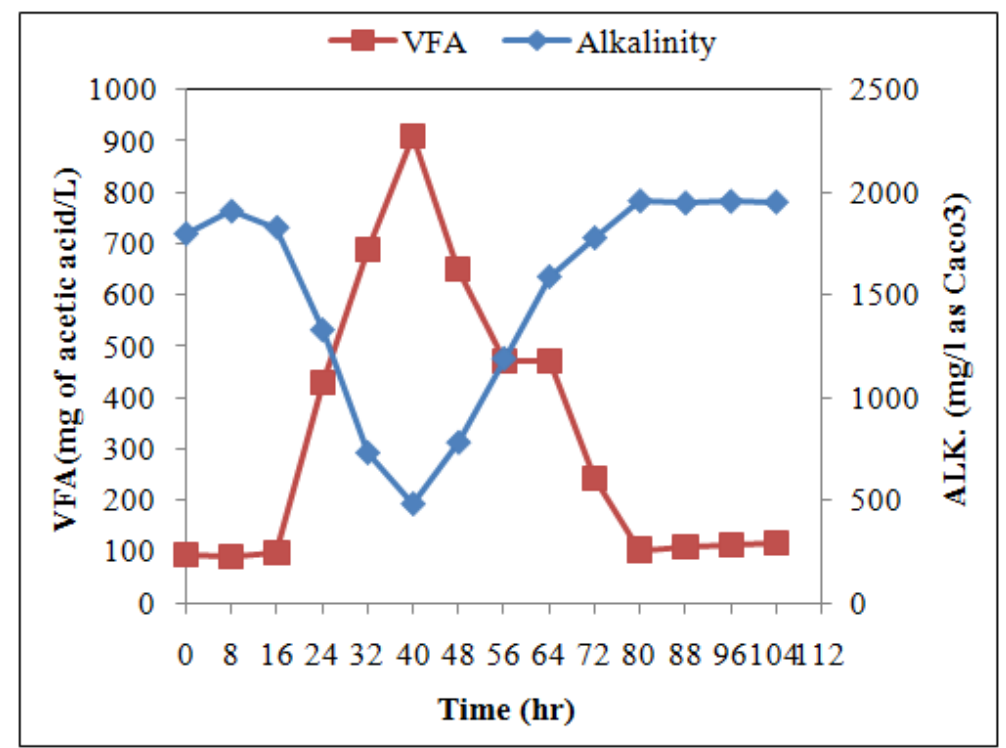

Fig.7b: change in VFA in (mg of acetic acid/L) and Alkalinity in (mg/l as Caco3) with time (hr) in (bench scale model, Run2).

With the increase of OLR, VFA/Alk increased this give the same effect of the PH but still give a earlier indication. So increasing VFA/Alk inhibit methane-forming bacteria, therefore gas production rate decreased. At the first $8 \mathrm{hrs}$, after increased OLR (hr no. 24), the VFA/Alk was 0.32 so gas production still not affected, but at the next 8 hrs VFA/Alk was 0.9 and the gas production decreased dramatically. Figure (7c) show the change in gas production rate in (L/8hr)) and VFA/Alkalinity ratio with time.

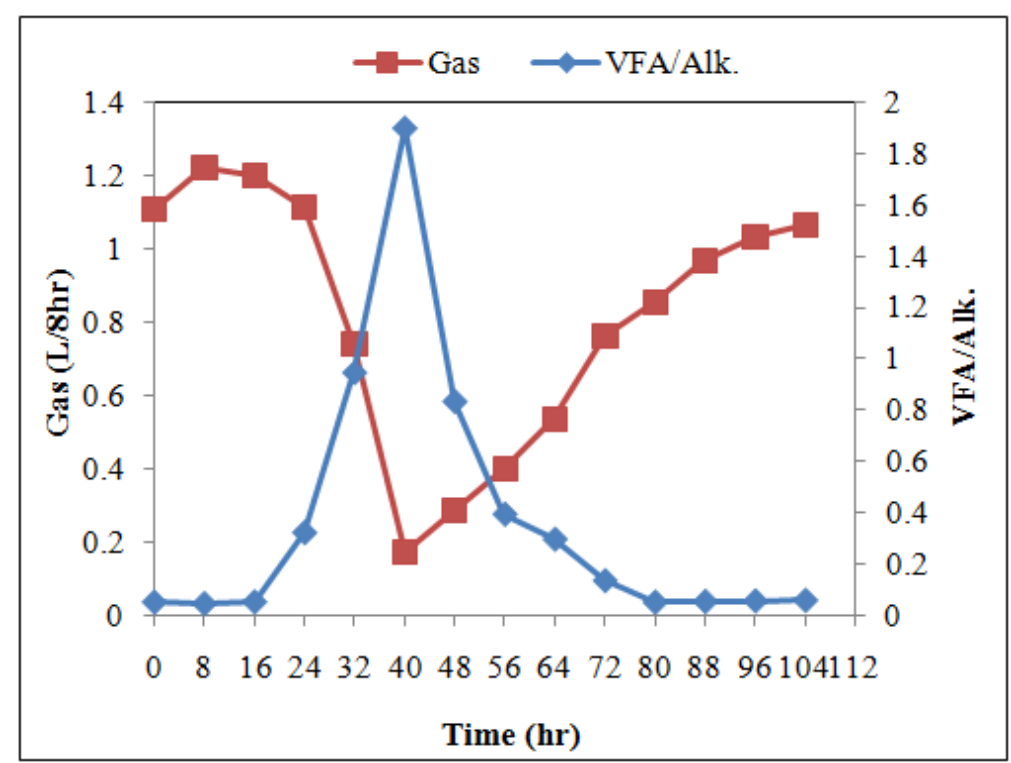

Fig.7c: change in gas production rate in (L/8hr) and VFA/Alk ratio with time (hr) in (bench scale model, Run2).

Programming the Arduino Code: Using the results of the bench scale model run 1 and run 2 the Arduino code programming was conducted to control the biological processes inside the digester automatically. Figure ( $8 \mathrm{a} \& 8 \mathrm{~b}$ ) show part of the code used to control the operational conditions, and its flowchart. If the $\mathrm{pH}$ between 6.4 to 6.8 , it is enough to only close the feeding pump no.2. If the $\mathrm{pH}$ between 6.4 to 6.8 , it is enough to only close the feeding pump no.2. If the PH was below 6 the control system will close pump no2 and open pump no. 1 to add lime dose. Then after one hour the system will again measure the $\mathrm{pH}$ if it is still below 6.4, the control system will re-pump another dose until the $\mathrm{pH}$ reaches 6.4. As soon as it reaches 6.4, the control system will add half dose of lime - that adjusted by operation time of the pump no.1- in addition to one dose of soda ash. 


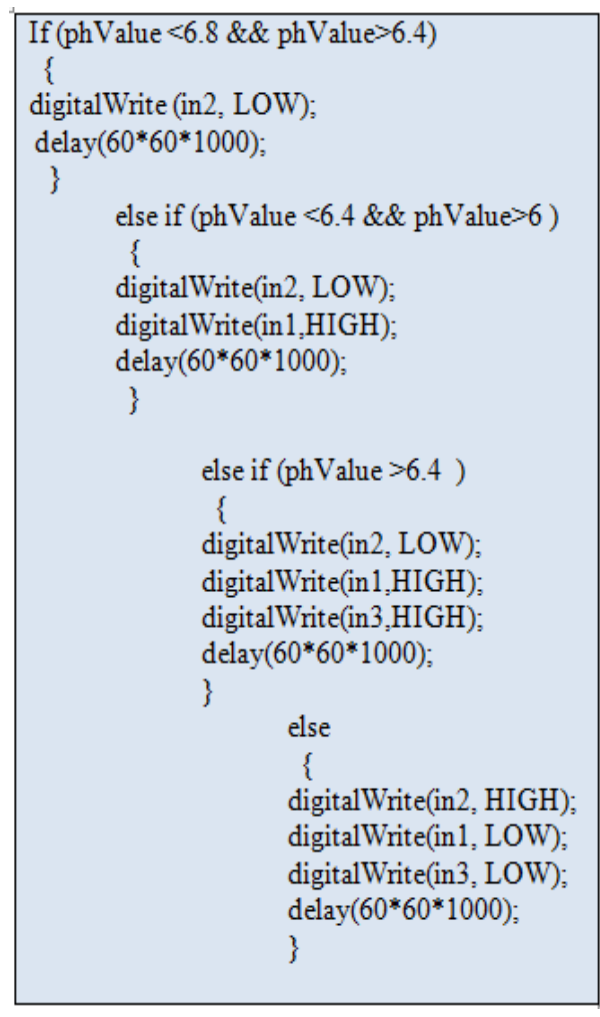

(a)

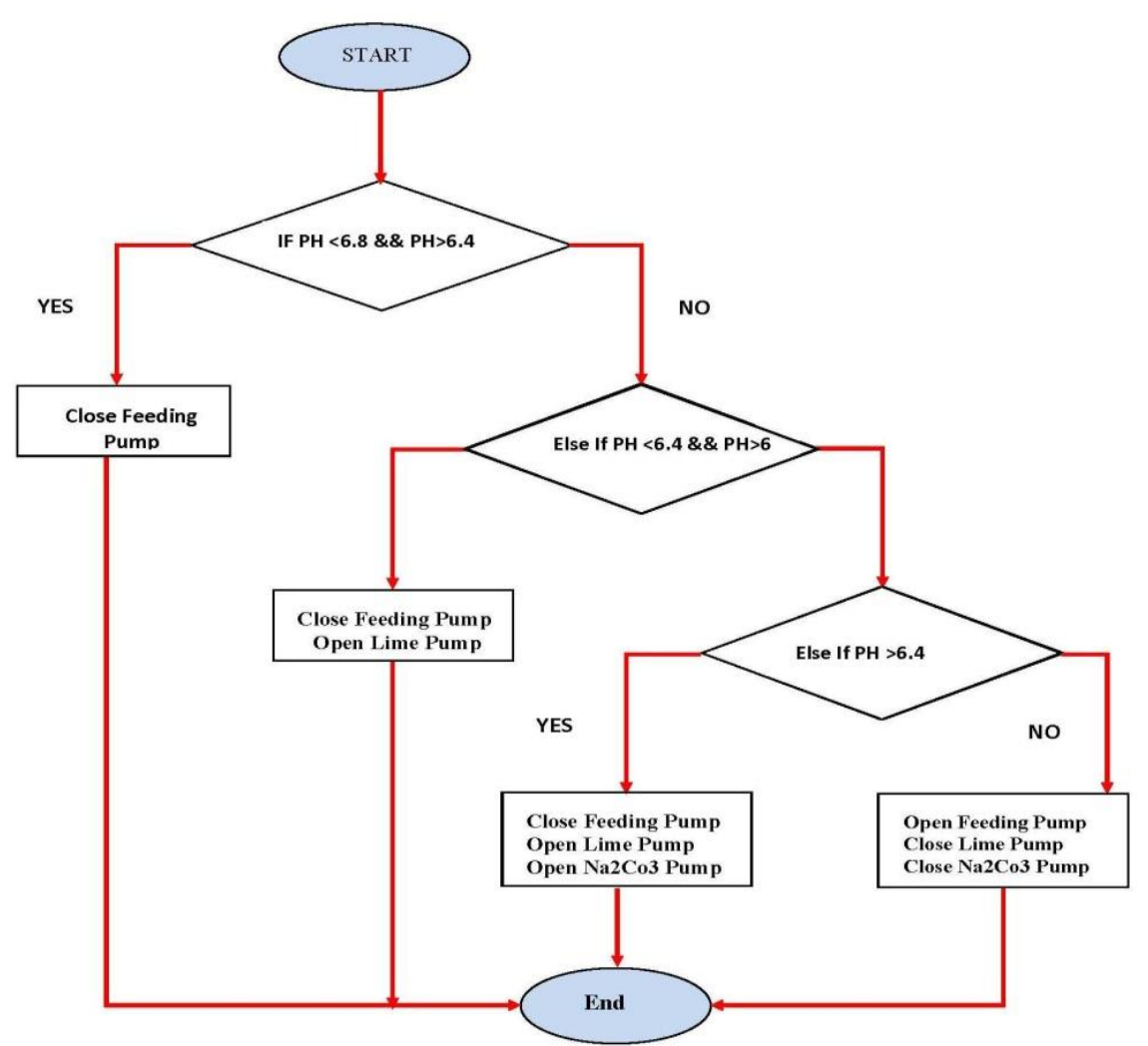

(b)

Fig.8a: the Arduino code that used to control the operational conditions

fig.8b: code algorithm implemented on Arduino.

Pilot Scale Results: For 40 days -startup period - the temp., pH, methane concentration, gas production rates, VFA, and alkalinity were monitored until measured parameter became stable. Then the dry solids (DS) and volatile solids (VS) in g/L were measured in the influent and in the effluent flow. Moreover, the removal percentage was calculated. Fig.(9a\&9b) shows the results.

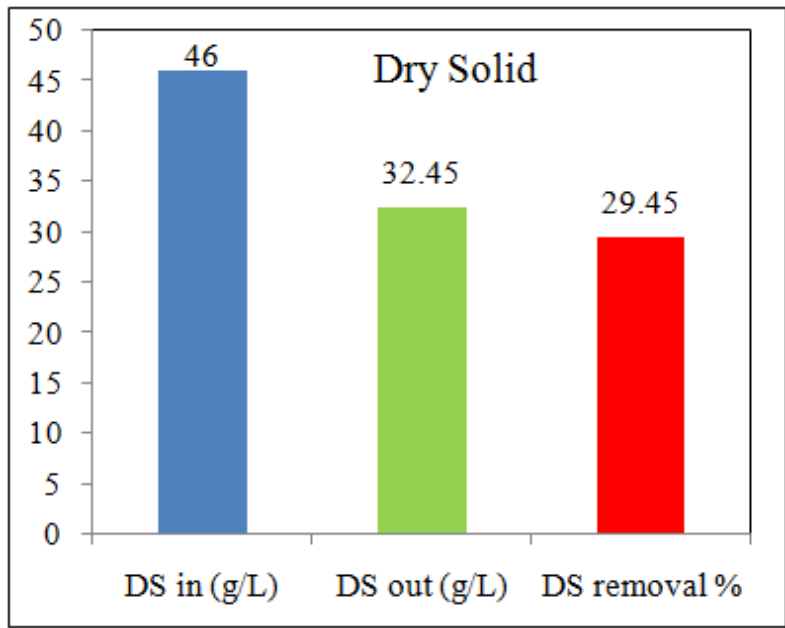

Fig.9a: DS removal efficiency

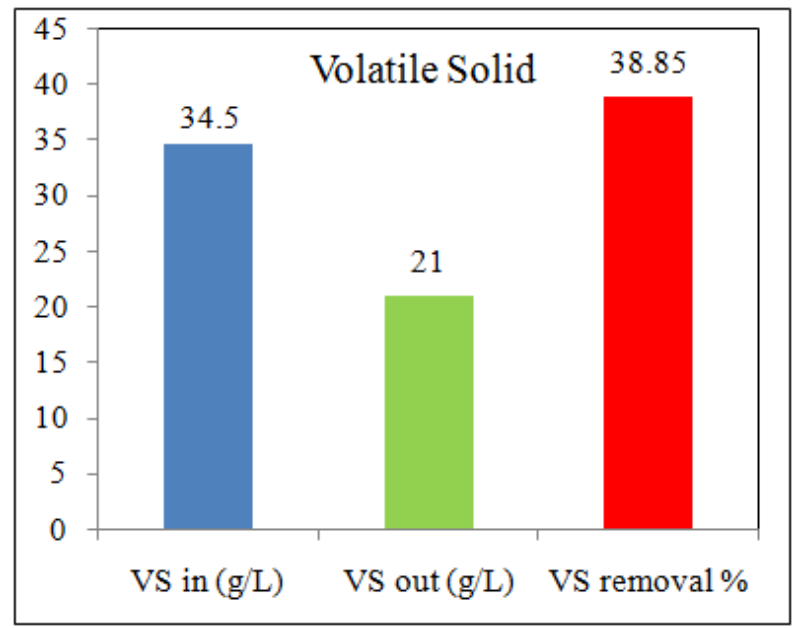

Fig.9b: VS removal efficiency

In order to test the automatically control by the Arduino and its programming code, and to study its effectiveness in recovery of digester without human intervention, a pilot scale model was built. An overload OLR was then applied. The recovery method by automatically control was monitored, recorded and analyzed.

OLR was increased from 1.5 to $9 \mathrm{~kg} \mathrm{VS} \mathrm{/} \mathrm{m} 3 / \mathrm{d}$ in order to reduce $\mathrm{pH}$ less than 6 , during that pumps control was closed, then opened in order to apply the Arduino control. With the increase of OLR, the pH decreased to 5.9 Therefore, feeding was stopped and four consecutive doses of lime $(0.6 \mathrm{~L}$ conc. $5 \%)$ added when pump 1 was opened by Aduino until the pH began to rise to 6.4. Then, three doses of soda ash ( $0.2 \mathrm{~L}$ conc. $5 \%)$ added by pump 3 when opened automatically by Aduino in addition to the $(0.3 \mathrm{~L}$ conc. $5 \%)$ of lime as the feed pump continued to be closed. This causes the $\mathrm{pH}$ to rise to 6.9 Figure (10a) show the change OLR in $\mathrm{kg} \mathrm{VS} / \mathrm{m} 3 / \mathrm{d}$ and $\mathrm{PH}$ with time.

VFA also increased to 1040 ( $\mathrm{mg}$ of acetic acid / liter) with the increase of OLR, due to the accumulation of VFA and the inability of methane-forming bacteria to consume it (Abdallah and Kennedy, 2013). Alkalinity was also reduced to 770 (mg / L as Caco3). as shown in fig.(10b). 


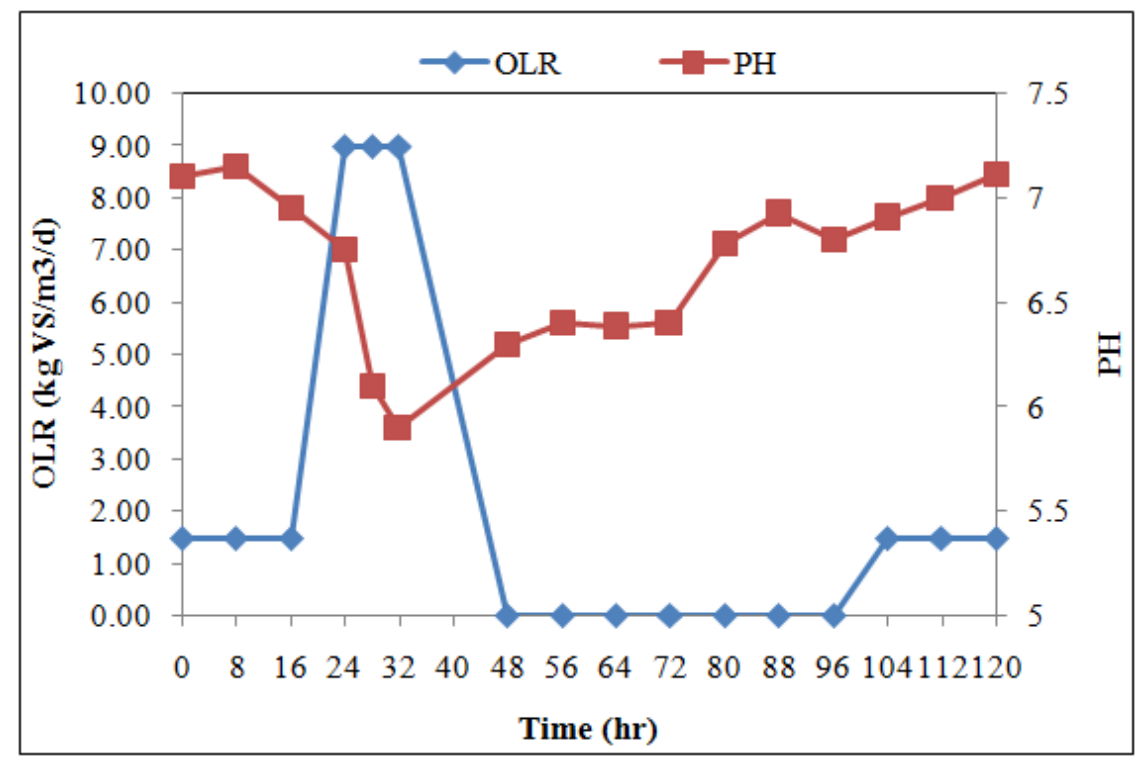

Fig.10a: change in OLR (kg VS/m3/d) and PH with time (hr) in (pilot scale model).

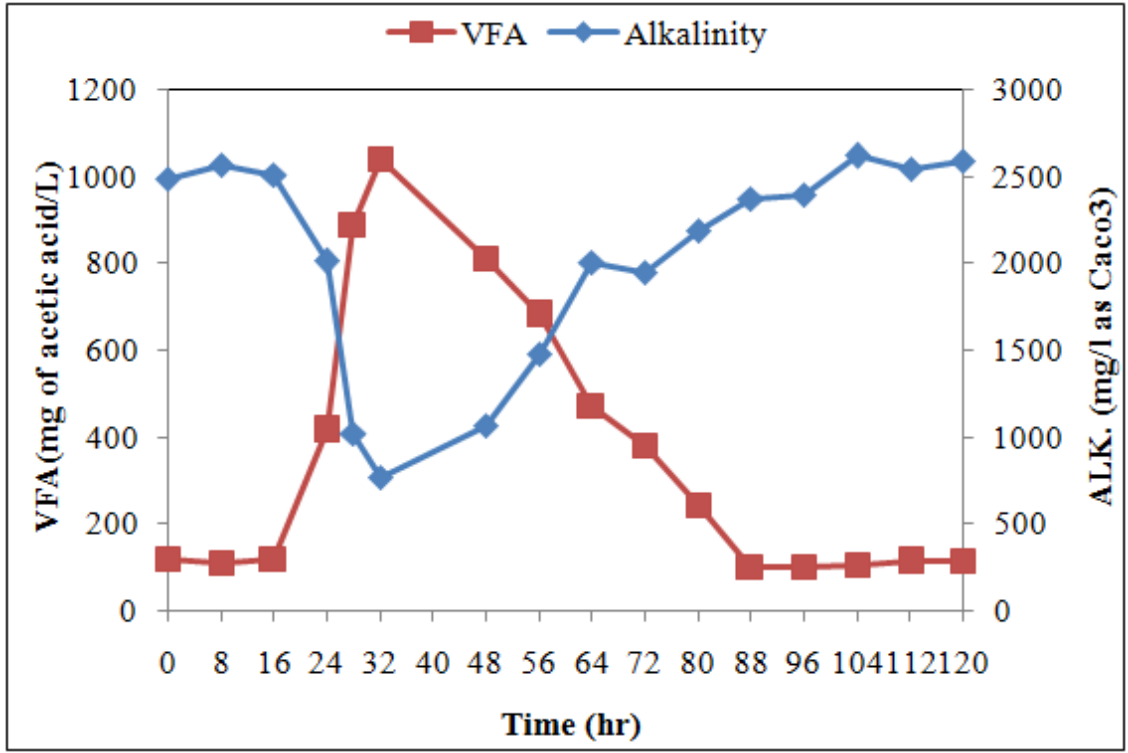

Fig.10b: change in VFA in (mg of acetic acid/L) and Alkalinity in (mg/l as Caco3) with time (hr) in (pilot scale model).

As a result, during the first 8 hours after increasing the OLR, VFA/Alk rose to 0.85 and the $\mathrm{pH}$ began to fall to about 6. There was also a significant decrease in the rate of gas production by about $50 \%$ and a decrease in the concentration of methane gas by about $60 \%$. As shown in figures (10c) and (10d). 


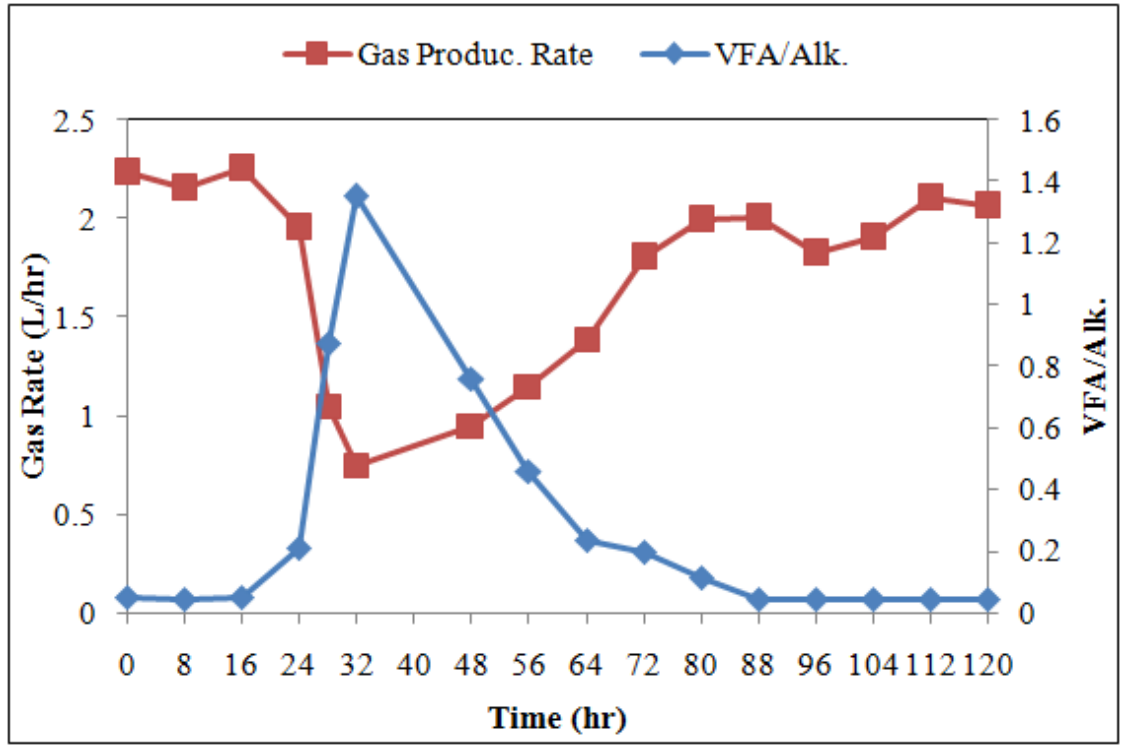

Fig.10c: change in gas production rate in (L/hr) and VFA/Alk ratio with time (hr) in (pilot scale model).

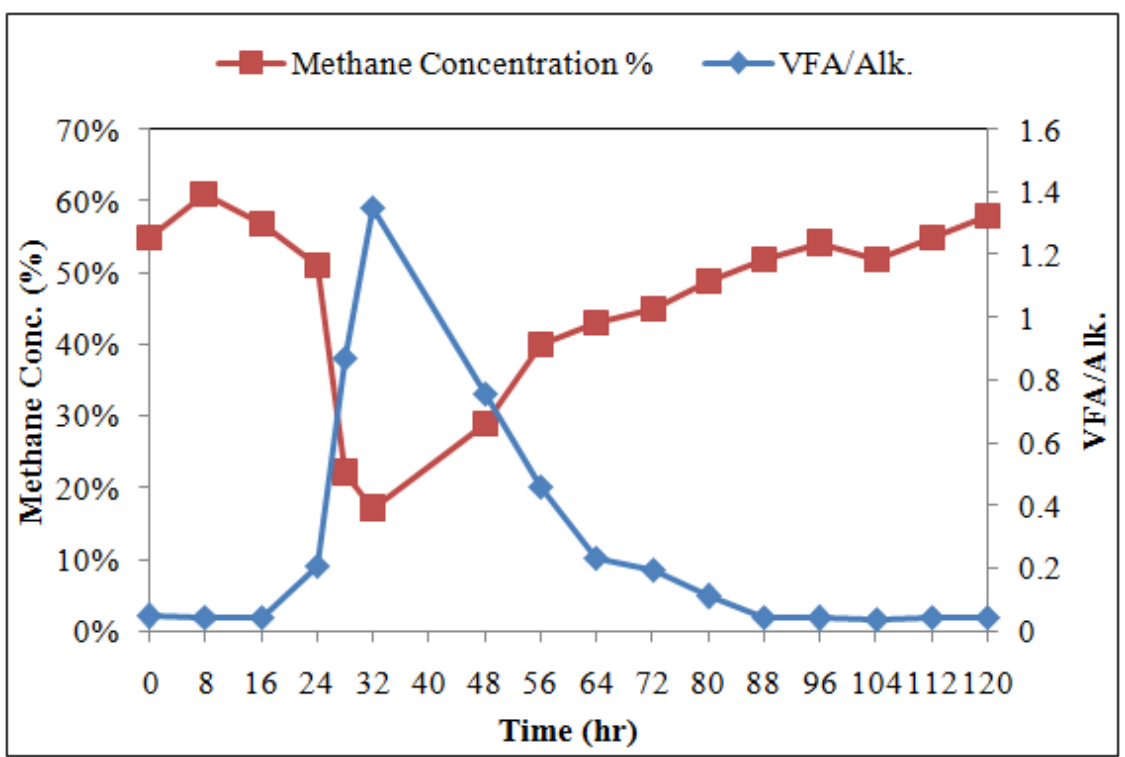

Fig.10d: change in Methane concentration (\%) and VFA/Alk. ratio with time (hr) in (pilot scale model).

\section{CONCLUSION}

The main cause of disruption of sludge digesters and its exit out of the work is their high sensitivity to environmental conditions, especially the $\mathrm{pH}$, which should be ranged between 6.8 and 7.2, meaning that, the allowable range of change is only 0.4. So, PH is the cornerstone of the biological processes in the digester and it is strongly influenced by the OLR and VFA/Alk ratio.

Relying on technology such as programming electric circuits in controlling sludge digester is highly effective. Unlike manual control which often disrupts the digester due to slow response. The actual change in $\mathrm{pH}$ begins when the VFA/Alk ratio reaches 0.8 , which affects gas production rate and methane percentage. Methane concentration is so important because it expresses the amount of heat energy that can be obtained when the gas is burnt.

The $\mathrm{pH}$ can be recovered by stopping the digester feeding only if the PH is between 6.5 and 6.8 . As soon as the pH drops to 6 or less the PH can be raised, using lime only, to 6.4 and more lime is not preferred because it will be accumulated without effect. Other antacids such as soda ash, together with lime, are needed to raise the $\mathrm{pH}$ above 6.4. The characteristics of the sludge are not the same, so similar laboratory studies should be carried out before Arduino programming is done for new treatment plants.

\section{REFERENCES}

A.M. Gibb, (2010). "New media art, design, and the Arduino microcontroller: A malleable tool". PhD thesis, Pratt Institute. Abdallah M., and Kennedy K., (2013). "Advanced Monitoring and Control of Anaerobic Digestion in Bioreactor Landfills". Biodegradation - Engineering and Technology.doi:10.5772/55715.

Chandra R., (2009)." Studies on production of enriched biogas using jatropha and pongamia de-oiled seed cakes and its utilization in I.C. Engines". PhD Thesis, Delhi: Centre for Rural Development and Technology, IIT. 
Demirbas A., Coban V., Taylan O., \& Kabli, M. (2017). Aerobic digestion of sewage sludge for waste treatment. Energy Sources, Part A: Recovery, Utilization, and Environmental Effects, 39(10), 1056-1062.doi:10.1080/15567036.2017.1289282.

Gerardi michael h.,(2003). " the microbiology of anaerobic digesters". Hoboken: wiley-interscience, print isbn: $978047-1206934$ ,online isbn: 9780471-468967.

Goldfarb, W., U. Krogmann, and C. Hopkins., (1999). "Unsafe sewage sludge or beneficial biosolids? Liability, planning, and management issues regarding the land application of sewage treatment residuals". Boston Coll. Environ. Affairs Law Rev. 26:687-768.

Gupta A, Kumar A, Sharma S, Vijay VK., (2013) "Comparative evaluation of raw and detoxified mahua seed cake for biogas production". 102:1514-21.

In 't Zandt M. H., Van den Bosch T. J. M., Rijkers R., Van Kessel M. A. H. J., Jetten M. S. M., \& Welte C. U., (2018). "Cocultivation of the strictly anaerobic methanogen Methanosarcina barkeri with aerobic methanotrophs in an oxygen-limited membrane bioreactor". Applied Microbiology and Biotechnology, 102(13), 5685-5694.doi:10.1007/s00253-018-9038-x.

J. Jeffrey Peirce Ruth F. Weiner and P. Aarne Vesilind., (1998). "Environmental Engineering (Fourth Edition",ch.10, Butterworth-Heineman.

Jay N. Meegoda, Brian Li, Kush Patel and Lily B. Wang., (2018) "A Review of the Processes, Parameters, and Optimization of Anaerobic Digestion”. Int J Environ Res Public Health. Oct; 15(10): 2224.

M. Banzi, (2009). "Getting Started with arduino". O'Reilly Media, Inc.

M. Margolis, (2011). "Arduino cookbook". " O'Reilly Media, Inc.".

Mignone Nicholas., (2005). “A Biological Inhibition/Toxicity Control In Municipal Anaerobic Digestion Facilities”.Article.

Mohammed Ali Musa, Syazwani Idrus , Che Man Hasfalina and Nik Norsyahariati Nik Daud. (2018) ”Effect of Organic Loading Rate on Anaerobic Digestion Performance of Mesophilic (UASB) Reactor Using Cattle Slaughterhouse Wastewater as Substrate", Int. J. Environ. Res. Public Health, 15, 2220.

Peter D. Minns, (2013). "C Programming For the PC the MAC and the Arduino Microcontroller System". Author House.

Schnaars, Ken., (2012). "What Every Operator Should Know about Anaerobic Digesters". Nashville: Operator Essentials.

Shujun Chen, Jishi Zhang and Xikui Wang., ( 2015). "Effects of alkalinity sources on the stability of anaerobic digestion from food waste", Waste Management \& Research, UNIV ARIZONA LIBRARY on October 9.

Taddese Girmay Teklehaimanot, Weldegebriel Berhie Abrha, Berhe Tadesse Abay, ( 2017)."Comparison of Sodium carbonate, Lime and Ash effects on Biogas Production"; International Journal of Engineering Development and Research ( IJEDR); Volume 5, Issue 4. , ISSN: 2321-9939.

Veronica Arthurson .,(2008). "Proper Sanitization of Sewage Sludge: a Critical Issue for a Sustainable Society". Appl Environ Microbiol.; 74(17): 5267-5275.

Wolfe R.S., (2011)." Techniques for Cultivating Methanogens in Methods in Enzymology". Volume 494. Academic Press; Cambridge, MA, USA. pp. 1-22. 